\title{
Learning to Become Lifelong Global Citizens
}

\author{
Soveacha Ros (Northern Illinois University)
}

\begin{abstract}
This study examines transition practices of four international male graduate students from Cambodia pursuing social science degrees at Northern Illinois University (NIU). An interview guide was designed and grounded in three questions: (1) How do informants describe their academic and social experiences during their first year at NIU?; (2) What adaptation resources do they have at their disposal (i.e. on NIU campus, in DeKalb and neighbouring communities, social networks in Cambodia and America)? How do these resources help them to adjust; (3) How do they view themselves as international students at NIU? And, how does this view play a role in their adaptation process?

The analysis is drawn upon four individual in-depth interviews. Two informants have been at NIU since August 2006 referred to as Senior 1 and Senior 2. The other two participants have been at NIU since August 2007and are referred to as Junior 1 and Junior 2.

Excerpts of critical markers accumulated from interviews are employed to emphasize key themes in the data. Implications for teaching and learning in multicultural education context and literature dealing with similar groups of students from South East Asia are also discussed.
\end{abstract}

\section{Résumé}

Le but de cet article est d'examiner les pratiques d'adaptation de quatre étudiants internationaux de troisième cycle, originaires du Cambodge et qui étudient à la faculté de Sciences de l'Université d' Illinois du Nord (UIN). Nous avons mis en place un guide pour les interviews où nous les avons interrogés sur les trois questions suivantes: (1) Comment nos informateurs décrivent-ils leurs expériences académiques et sociales pendant leur première année à UIN ? ; (2) À quelles ressources d'adaptation ont-ils accès (par exemple sur le campus de l'UIN, à DeKalb et dans le voisinage, dans leurs réseaux de relations sociales au Cambodge et aux États-Unis) ? Comment ces ressources leurs servent-elles à s'adapter ? ; (3) Comment se perçoivent-ils eux-mêmes en tant qu'étudiants internationaux à UIN ? Et quel rôle joue cette perception dans leur processus d'adaptation?

Cette analyse puise dans les interviews de ces quatre individus. Deux informateurs sont à la UIN depuis août 2006. Nous nous réfèrerons à eux avec les mots anglais Senior 1 et Senior 2. Les autres deux participants sont à la UIN depuis août 2007. Nous nous réfèrerons à eux avec les mots anglais Junior 1 et Junior 2. Nous utiliserons des références critiques de quelques extraits des interviews afin de mettre l'accent sur des thèmes clés dans les données. Pour conclure, nous examinerons les implications pour l'enseignement et l'apprentissage dans des contextes éducatifs multi culturaux et analyserons les résultats d'autres recherches avec des groupes d'étudiants similaires, originaires de l’Asie du Sud Est.

...When sitting in class back in Cambodia, we don't even sit with crossed legs when the teacher is present. That is our Khmer culture.

But, when sitting in American classrooms, some of them sit in whatever positions 
they like.

Some people wear hats in class.

Some fall asleep while sitting in class.

Some rest their legs on chairs

-sit in any position.

That's a cultural challenge to me.

Even though I've been here for more than a year now,

I still feel shocked seeing all these

and still feel it's not right.

However, I don't judge the different acts.

We understand that it's their culture

I try to understand them.

It's their culture.

We can't be like them

because we have our own identity.

I think it's one of our challenges.

We must understand

what the reality of culture of this [American] society is...

Senior 1, a Cambodian student at NIU

...My [American] teacher picked up me from an airport [in San Francisco]

when I first arrived in the United States.

The first thing that surprised me

was his fast speed driving at around 7 or $8 \mathrm{pm}$.

I was thinking to myself that he was driving too fast

for his aging eyes.

He's around 60-70 years of age.

If this were Cambodia,

there might have been a road accident sooner than you knew.

That has to be my all time most surprising experience here.

When we arrived at [his] home,

it was beautiful.

His house was small but beautiful

-well-organized.

It's different from our [Cambodian] houses.

His decorations were beautiful.

His house was small but beautiful...

Junior 2, a Cambodian student at NIU

\section{BACKGROUND}

Cambodian graduate students at Northern Illinois University are increasingly aware of how cultural and educational settings in the United States differ from those at home. As illustrated by the two quotes, first impressions indicate great 
contrast between ways of studying and living in Cambodia and America. Home culture plays a significant role in shaping how individuals view their world; they could begin to see the world differently when being exposed to a new culture..

Clifford Geertz (1973) and Lilia Abu Lughod (1993) write about concepts related to studying and interpreting one's culture. Both Geertz (1973) and Abu-Lughod (1993) define culture against the traditional definition of culture; they see culture as something that can be flexible, changeable, and interconnected-not as linear as the traditional definition of culture. AbuLughod defines culture as "something that was learned and therefore could change" (p. 9). Geertz defines culture as webs when he states that "man is an animal suspended in webs of significance which he himself has created. I take culture to be those webs” (p. 5). Inspired by the two anthropologists, my perception and definition of culture is that people create their own culture and in turn culture influences them. The Cambodian students in this study go through their transitional period where they learn to adjust to a new cultural and educational system. Abu-Lughod (1993) also agrees with Geertz that studying a culture is to focus on "individuals and the particularities of their lives" to better understand their culture and our ways of living (p. 27).

The purpose of this study was to explore cultural and educational challenges among Cambodian graduate students at Northern Illinois University and how the challenges allowed them to learn to become lifelong global citizens.

\section{LITERATURE REVIEW}

\section{Cambodian child rearing practices}

This study focuses on Cambodian culture as a unique group. While viewing the Cambodian student population as an individual cultural group, it is important to look at how Cambodian students have certain values resulting from how they are nurtured. Commonly, it is known that Cambodian fathers traditionally do not get involved in childrearing as they might think that they are family breadwinners. Thus, fathers usually go out to work and return home expecting meals already cooked. This is how many Cambodian fathers share responsibilities in rearing children. According to Buddha's teaching, parents are supposed to be the "indoor gods" (Preah Knong Pteah). This means that children respect their parents very highly.

When it comes to educating children, Cambodian parents do not usually get very involved in the process, and they rarely attend school meetings. Anything related to school, Cambodian parents mostly depend on teachers. Smith-Hefner (1999) stated that some Cambodian parents stick to the idea that pushing their children to study is worthless, believing that every achievement of their children depends on their Veasna -destiny or fate -from their previous life. Even though some Cambodians encourage and support children's achievements, there is little push to excel among many Cambodian families (1999). 


\section{Cultural values of Cambodian-American college students}

Since there are limited studies on Cambodian-Cambodian college and/or graduate students, we will look at Cambodian American college students who appear to be the closest group referring to this study. Many educational policy makers fail to see Cambodian American students as a single cultural unit of successful Asian American students. In addition to this overgeneralization, there are literature reviews demonstrating how some Cambodian American students at a certain geographical location have academic challenges. Studies have been conducted examining how successful Cambodian American college students perceive traditional cultural values in relation to their schooling experiences (Chhuon, Hudley, Macias, 2006). By overlooking Cambodian American students as a single Asian American group, Cambodian-Americans become unseen and under-represented. It is interesting to note that the Cambodian population is rapidly rising together with their educational difficulties while living and studying in America. Oftentimes, educational researchers see a high graduation rate of Asian American as a model minority and leave out high dropout rates, delinquency, and language barriers experienced by many Cambodian American students. There is little research on this particular group (2006). Examining the influence of Cambodian cultural values on academic achievement, it is important to note that Karmic law, the belief in the predetermination of one's fate is its fundamental value derived from Theravada Buddhist beliefs (2006). As a result of this belief, some research studies find that Cambodian parents usually have little involvement in their children's educational process and leave all responsibilities to teachers and schools. For a traditional norm, Cambodian parents think that the school itself is totally responsible for educating their children (2006).

To better understand Cambodian American students, other studies compare values of Laotian, Vietnamese, and Cambodian people. Caplan et al. (1989) argued that the educational accomplishments of Vietnamese and Laotian refugee groups can be attributed to traditional values that center upon family, respect, and obligation. This research indicates that luck, fate, and intelligence are less influential for academic achievement than controllable variables related to effort and perseverance. It is interesting that this research finds that LaotianAmericans in their studies, like Cambodian-Americans, subscribe to Theravada Buddhists traditions. Thus, while Laotian-Americans' academic success is said to be rooted in their cultural beliefs (Caplan et al., 1989), values from similar Buddhist traditions are often cited as conflicting with Cambodian-American students' successful schooling (Caniff, 2001; Smith-Hefner, 1999). At the same time, another study argues that traditional Cambodian cultural values provide students with a positive coping mechanism for the various challenges they face in school (Sin, 1991); for example, maintaining a patient attitude facilitates the personal drive necessary for these Cambodians to overcome the many social, financial and education challenges they experience. Cambodian-American 
students' patient behavior is viewed as a temporary coping style and over time, as students learned English, became more outspoken, and pushed forward toward educational goals. Sin (1991) also added that non-competitive attitudes of the informants is seen as a characteristic that promotes individual resilience. Hence, patience as a cultural norm helps families cope with poverty, language barriers, and other adjustment issues (1991).

\section{METHODOLOGY}

The primary interview language was Khmer. The interviews were audio taped and transcribed; all of the direct quotes were directly translated from the original transcripts. During each interview session, there were fieldnotes and immediate jottings of important information. The fieldnotes served as primary data source when it came to analyzing data. We followed up the interviews by informally conversing with the participants 1-5 times to learn more details from the participants' transition experience.

Throughout the study, we minimized our biases by being aware of being insiders of the Cambodian sub culture. We "stepped out" and examined transitional practices of the participants using an interpretive foundation and an ethnographical perspective (Powdermaker, 1966; Geertz, 1973; Sunstein \& Chiseri-Strater, 2007). We were also interested in revealing their personal transition experiences as we are "insiders" of the subcultures (Sunstein \& Chiseri-Strater, 2007, p. 7).

The interview questions were categorized into three major areas: educational background prior to the American experiences (particularly freshman year at college), first year academic and social life experiences on NIU campus, and self reflection as an international student both on and off campus. The first two areas aim to demonstrate similarities and differences of freshman year of college life outside America in contrast to first year at NIU.

Data analysis aimed to discover the implicit and explicit meanings in the Cambodian students' responses. The findings were seen through our eyes grounded in Ricoeur's three-step technique: analyzing "objective” data, viewing the "subjective" items of narratives, and inferring both in relation to one another. Common themes were also coded. After coding, we re-read the coded themes and discovered three predominant themes that merged and supported the inspiration of learning to become lifelong global citizens.

\section{FINDINGS AND DISCUSSION}

After analyzing the data, there were three key findings: motivational factors, sense of belonging, and learning to become lifelong global citizens.

\section{Motivational Factors}

Although Smith-Hefner (1999) mentioned earlier that Cambodian parents do little to encourage their children for educational excellence, this study found a 
difference: the informants' families played a major role in motivating them to pursue their education in the United States. As their families needed their help financially, they felt obliged to successfully complete their degrees at NIU. All participants expressed their desire to get a well-paid job by applying the knowledge learned during their program at NIU to their future workplace.

A participant even described how his family pushed him to study hard and stay on focus. The caption below demonstrates how his family strongly encouraged him:

Out of my family members [in Cambodia], I miss my younger brother the most because he suffered brain damage at a very young age due to some sort of high body temperature. So, nowadays, he doesn't mentally function well. He doesn't go to school. When I was in Cambodia, during my 4 year college, I was very close to him. All day, after school, I stayed with him and bought him snacks. Now that I'm here [in DeKalb], I miss him the most. I miss him more than anyone else. And, I feel sorry for my mother because she has to run her daily business and care for him daily. -Junior 1

\section{Sense of Belonging}

Even though the Cambodian students had traveled abroad prior to coming to NIU, they were experiencing loneliness, homesickness, and depression to some extent. While being away from home, it was extremely difficult for them. Technology (i.e. telephone, email, and internet) enables them to keep in touch with their family members and good friends.

The Cambodian students were concerned about making new friends of different cultures. Most of them said it would be nice to start off with at NIU by having a place they can belong to and meet people from the same culture before blending in any new culture. Fortunately, the NIU community has a strong network assisting international students -academically, socially, and culturally. Another way to feel connected to home, all participants brought postcards, paintings, sculptures, and home music. These items made them feel more at home. Based on these practices, it shows that they can create their own "corner," where they can interact with the cultural group members using their native language.

The informants wished for a place to which they could form a spiritual attachment. Senior 1 made a comment about having a place to belong as followed:

Before meeting any other cultural group of students, we [the Cambodians] should meet in our Cambodian friendship circle to start to feel we're one unity. By doing so, newcomers could feel that there's something they can rely on. If we place a person into a huge circle, but we don't feel that we belong to the group we still feel isolated. We still don't feel strong. If we place that same person in something solid 
which would make him/her feel included—although it's small—I think it's better than having that person in the big circle. Then we can begin introducing that person to other groups more easily as he/she has something to rely on already. When having any issue, that person already knows that there're other Cambodians whom he/she can go consult with or seek advice. This must be a lot better than having no sense of belonging to the group.

\section{A Trend: Becoming Lifelong Global Citizens}

A global citizen is defined here as someone who travels outside his or her birth country for an extensive period of time (at least three months), specifically to another country experiencing a different set of beliefs, behaviors, and cultural practices. To become a lifelong global citizen, an individual needs to go through some forms of cultural transformation or transition either by living, working, or studying in a new national culture. It should be noticed that anybody who has not traveled internationally can also possibly become a global citizen through other means; however, those individuals are not part of our research interest group.

Facing freezing, silvery winters after growing up in a tropical environment was one of many differences the Cambodian students encountered upon coming to NIU. In addition to academic challenges, their work is to overcome huge cultural and educational differences between Cambodia and the United States. Looking at the above two findings, we saw the respondents as people going through a transitional period, which socially and culturally transform them during their adult developmental process. In other words, they are like frogs in a well, and they have gone out of it in order to witness the bigger sky. One of them has visited his original "well" and started to reflect how big the real world actually is: he admits that it is not as narrow as the sky he saw from the bottom of the well. In fact, it took a lot of effort to climb up against the well wall in order to get out of it. Senior 2 thought of pursuing a doctorate right after graduating from his master's program. Speaking of the frog in the well analogy, frogs were referred to as the respondents. The wall of the well referred to their home culture boundary, which shapes their way of looking at and interpreting the sky-their world view. The wall of the well is their cultural lens. The bigger sky is viewed as the travel experiences they have had so far.

All of the Cambodian students expressed that they have become more mature and independent in terms of living on their own and doing more household chores. In addition to becoming more responsible individuals, they view themselves as cultural ambassadors who bring with them their heritage and would like to put it out there to share with local people and class members. They are very proud of their culture and heritage. At the same time, they have been learning a lot from friends of different cultures. They have also learned to admire and respect other cultures. By experiencing diverse cultural experiences 
on and off the NIU campus, Senior 1 specifically said "I give two thumbs up to Cambodian culture, but it does not mean that I give thumbs down to other cultures”. This portrays that he values not only his home culture but also the opportunity to learn from different cultures. To understand American culture better, he mentioned that he needs direct "interaction with Americans" both in and outside classroom.

While going through their transition period and facing challenges, the Cambodian students see themselves as emerging global citizens. They have been learning to be receptive to cultural and educational differences. Junior 2 thought studying at NIU is not as hard as life during 1975-1979 Khmer Rouge killing field regime in Cambodia that his parents went through and survived the era. He stated that, "this is nothing compared to genocide... I know it's hard to study in America, but I think this is how I can understand other cultures better." In a nutshell, the participants have learned to share a common understanding that they should learn to accept the differences and at times, to agree to disagree.

\section{CONCLUSION}

Transitional experience is seen as an alternative of culture shock. The frustrations and issues in the culture shock process are crucial to an understanding of change and development experiences, and that such transitional experiences can be a source of higher levels of personality development (Adler, 1975). This research project also draws implications for teaching and learning in multicultural education context and literature dealing with international students specifically those from South East Asia studying at American higher educational institutions. A broader significance of our study is opening doors to researching Cambodian student populations studying in other American universities. These populations have been much studied while the participation of Cambodian students keeps increasing in Northern American universities. Thus, this research offered insights to higher education practitioners and policy makers.

More research on Cambodian graduate students pursuing degrees in American universities should be done to confirm or disconfirm the above three findings. It will also be interesting to conduct similar research on Cambodian graduate students pursuing degrees in Canadian universities.

\section{ACKNOWLEDGEMENTS}

The author wishes to acknowledge the helpful comments and suggestions of Dr. Rethy Chhem. Special thanks to the Dr. Chhem for providing his knowledge and expertise. 


\section{References}

Abu Lughod, L. (1993). Writing women's worlds: Bedouin stories. Berkerly, CA, USA: University of California Press.

Caniff, J.G. (2001). Cambodian Refugees’ Pathways to Success: Developing A Bi-cultural Identity. New York, NY, USA: LFB Scholarly Publishing.

Caplan, N., Whitmore, J.K. \& Choy, M.H. (1989). The boat people and achievement in America, a study of family life, hard work and cultural values. Ann Arbor, MI, USA: The University of Michigan Press.

Chhuon, V., Hudley, C. \& Macias, R. (2006). Cambodian-American college students: cultural values and multiple worlds. Paper presented at the Annual Meeting of the American Educational Research Association (AERA). San Francisco, CA, USA, 11-7 April 2006.

Geertz. C. (1973). The interpretation of cultures. New York, NY, USA: Basic Books.

Powdermaker, H. (1966). Stranger and friend: The way of an anthropologist. New York, NY, USA: Norton.

Ricoeur, P. (1981a). The model of the text: meaningful action considered as text. In J. Thompson (Ed.), Hermeneutics and the human sciences, Cambridge, MA, USA: Cambridge University Press, pp. 197-221.

Ricoeur, P. (1981b). What is text?: Explanation and understanding. In J. Thompson (Ed.), Hermeneutics and the human sciences, Cambridge, MA, USA: Cambridge University Press, (pp. 145-164.

Robinson, S. (1998). Issues in Curriculum and Instruction: Effects of Multiculturalism on the Community College Curriculum. Available at http://www.eric.ed.gov/ERICDocs/data/ericdocs2sql/content_storage_01/0000019b/80/1 5/dd/4d.pdf Accessed 20 Feb 2010.

Sin, B. (1991). Socio-cultural, psychological and linguistic effects on Cambodian students' progress through formal schooling in the United States. Unpublished Doctoral Dissertation, University of Oregon.

Smith-Hefner, N. (1999). Khmer American: Identity and moral education in a diaportic community. Berkerly, CA, USA: University of California Press.

Sunstein, B.S. \& Chiseri-Strater, E. (2007). Field working: Reading and writing research. Boston, MA, USA:Boston University Press, p. 1-64.

Soveacha Ros is a Doctoral Candidate, Department of Counselling, Adult and Higher Education, Northern Illinois University. He can be reached at soveacha2002@yahoo.com. 